

Sociologia da fotografia e da imagem, de José de Souza Martins. São Paulo: Editora Contexto, 2008, 207 páginas. 


\title{
Documento do imaginário social ${ }^{*}$
}

\author{
Simonetta Persichetti $* *$
}

No início dos anos 60, um livro escrito pelo sociólogo francês Pierre Bordieu - Un art moyen: essais sur les usages sociaux de la photographie (sem tradução, mas seria mais ou menos Os usos sociais da fotografia) - trazia à tona a fotografia como um meio de integração social e uma forma de ajudar a compreender papéis dentro de uma sociedade. Ou seja, a maneira como uma sociedade cria por meio de imagens uma imagem de si própria. A idéia da representação de um cotidiano, mas também de ritos sociais.

Nesta linha - a discussão do imaginário da e na fotografia - é o que o sociólogo José de Souza Martins trabalha. E não é de hoje. Seu mais recente livro, Sociologia da fotografia e da imagem [a obra reúne textos já apresentados (em congressos ou publicados parcialmente em outras obras, resultado também das reflexões debatidas em seu curso de Sociologia Visual, ministrado na Universidade de São Paulo) de 2000 a 2002] trata e discute justamente esta questão - a falácia da credibilidade ou imparcialidade fotográfica.

A fotografia, inventada dentro de uma época positivista - primeiras décadas do século XIX - criou e referendou sua posição como espelho do real, mimese de um mundo sem nenhuma interferência de um olho pensante, a falsa idéia de um registro documental isento: prova de um discurso oral ou escrito. Contra esta crença, vários pensadores da fotografia tentaram se insurgir e, dentro dessas linhas de pensamento, também a sociologia.

\footnotetext{
* Esta resenha, com pequenas alterações, foi publicada pela autora, originalmente, no caderno Cultura do jornal O Estado de S. Paulo, em 16 de novembro de 2008.

** Simonetta Persichetti, jornalista e critica de fotografia, é doutora em Psicologia Social pela Pontifícia Universidade Católica de São Paulo e professora do Mestrado em Comunicação da Universidade Estadual de Londrina. Escreve sobre fotografia para $O$ Estado de S. Paulo e coordena a pesquisa e publicação da Coleção Senac de Fotografia. É autora dos livros Imagens da fotografia brasileira I e II, publicados pela Estação Liberdade e Senac.
} 
Ao tecer textos evidenciando a fotografia como protagonista e não apenas como suporte de outras formas de expressão, o autor demonstra que "o icônico é essencialmente expressão de uma necessidade do imaginário, uma linguagem e um discurso visual".

Rebate a idéia de que a fotografia "congela" momentos, deixando bem claro que é o contrário: cada imagem narra ou cria uma história. Uma conversa árdua, visto que há muito pouco as ciências sociais passaram a se interessar pela fotografia como documento por si só, portadora de uma narrativa própria criada dentro de circunstâncias sociais. O que ele defende é o reconhecimento da imagem como documento do imaginário social e não como registro factual de uma realidade social. E muito menos como ilustração. Para quem quer estudar ou pensar fotografia - algo fundamental na sociedade contemporânea - os textos de Martins são fundamentais. Não entregam receitas de leitura ou compreensão da imagem, mas instigam a pensar em seu papel como representante da imaginação coletiva de determinado momento social.

Como todo cientista, parte de perguntas, de dúvidas: “Quanto há de testemunhal numa fotografia? Quem nos garante que a fotografia formalmente similar e precisa, e aparentemente objetiva (o que foi fotografado era o que estava lá, nem mais nem menos), é o documento verdadeiro do que as pessoas vêem, e sobretudo sentem, pensam, fazem e são?"

Assim, ao começar o livro discutindo fotografia e vida cotidiana, ele apresenta um filme emblemático para muitos fotógrafos: Blow up, de Antonioni, realizado em 1966, e que no Brasil estranhamente recebeu o nome de Depois daquele beijo. É nessa obra de ficção que a polissemia fotográfica aparece com força e, como bem lembra Martins, não é porque uma obra é ficcional que ela é menos real. Portanto, é uma interpretação de um real que não se deixa simplesmente congelar ou aprisionar, mas que a cada olhada nos permite novas significações, novas possibilidades para entender representações da sociedade num certo ou determinado período sócio-histórico. 
Para além do cotidiano, existem os ritos da sociedade, formas que a ajudam a se estruturar e o autor apresenta um belo ensaio sobre as fotografias dos atos de fé no Brasil, realizado por cinco fotógrafos com olhares diferentes sobre esses temas. Ao tentar analisar essas imagens, Martins nos conduz para a questão da imaginação fotográfica - os vários modos de ver, que pertencem à imaginação do fotógrafo, por um lado, e de quem decifra imagens, por outro. Discussão que leva também ao terceiro texto, no qual analisa o trabalho do fotógrafo Sebastião Salgado, mais especificamente seu ensaio Exodos. E, aqui, surge o tão falado embate entre documentação e estética, como se uma fosse excludente da outra, idéia com que Martins não concorda. Claro que existe sempre uma busca, ou melhor, uma narrativa estética ao se criar um discurso, seja ele qual for. Assim como no primoroso ensaio O impressionismo na fotografia e a sociologia da imagem, em que percebemos com mais vigor sua idéia da necessidade de aprender a ver.

E, para não ficar somente na teoria, Martins apresenta num dos capítulos do livro seu ensaio fotográfico sobre o Carandiru durante o processo de desativação do presídio. Um estudioso com as duas visões da análise imagética: a teoria e o fazer. "Decifrar o que se esconde por trás do visível ou do fotografável continua sendo um desafio para os cientistas que se documentam com expressões visuais da realidade social", explica.

Na tessitura de seu pensamento - formado, aliás, por muitos estudos sobre história da fotografia e fotógrafos - Martins chama a atenção para a necessidade de uma sociologia do conhecimento visual para aprender a ler e interpretar imagens, em especial a fotográfica: "Sociólogos e antropólogos precisam muito mais do que uma foto para compreender o que uma foto contém." E assim é, pois desde muito alguém já disse que a fotografia é um tipo especial de conhecimento. 